\title{
KARAKTERISTIK LAPISAN GRAPHENE OXIDE YANG DIBUAT DENGAN TEKNIK UV OVEN SPRAYING SEBAGAI ELEKTRODA SEL SUPERKAPASITOR
}

\author{
TITIS AMELIA, NORMAN SYAKIR, AYI BAHTIAR, FITRILAWATI* \\ Departemen Fisika Fakultas MIPA Universitas Padjadjaran, \\ Jl. Raya Bandung-Sumedang Km 21,Jatinangor 45363 \\ *email : fitrilawati@phys.unpad.ac.id
}

\begin{abstract}
Abstrak. Reduced Graphene Oxides (RGO) merupakan kandidat bahan elektroda superkapasitor yang menjanjikan. Lapisan tipis $\mathrm{GO}$ pada substrat $\mathrm{Cu}(\mathrm{Cu} \mid \mathrm{GO})$ dibuat dari dispersi graphene oxide (GO) menggunakan teknik UV oven spraying dengan jumlah pengulangan deposisi sebanyak 25 kali. Kinerja elektroda $\mathrm{Cu} / \mathrm{RGO}$ diuji dengan pengukuran Cyclic Voltammetry (CV) pada model sel kapasitor elektroda tunggal $(\mathrm{Cu} \mid \mathrm{GO}-\mathrm{Pt})$ dan model sel kapasitor elektroda ganda $(\mathrm{Cu}|\mathrm{GO}-\mathrm{Cu}| \mathrm{GO})$. Pengukuran dilakukan pada rentang tegangan $-1,0 \mathrm{~V}$ sampai $-0,1 \mathrm{~V}$ dengan variasi scan rate antara 25 - $125 \mathrm{mV} / \mathrm{s}$. Kurva cyclic voltammogram (CV) tersebut digunakan untuk menentukan nilai kapasitansi spesifik (Csp), daya spesifik (Psp) dan energi spesifik (Esp) dari model superkapasitor.
\end{abstract}

Kata kunci: graphene oxide, kapasitansi spesifik, daya spesifik, energi spesifik, superkapasitor

\begin{abstract}
Reduced Graphene Oxides (RGO) is a promising candidate as material for supercapacitor electrodes. material merupakan kandidat bahan elektroda superkapasitor yang menjanjikan. Graphene Oxide thin films on $\mathrm{Cu}$ substrate $(\mathrm{Cu} \mid \mathrm{GO})$ were prepared using GO dispersion by UV oven spraying method with number of spraying repetition of 25 layers. Performance of $\mathrm{Cu} \mid \mathrm{GO}$ as supercapacitor electrodes were measured using Cyclic Voltammetry (CV) with single electrode cell model $(\mathrm{Cu} \mid \mathrm{GO}-\mathrm{Pt})$ and double electrodes cell model $(\mathrm{Cu}|\mathrm{GO}-\mathrm{Cu}| \mathrm{GO})$. The $\mathrm{CV}$ measurement were conducted in potential window of $-1.0 \mathrm{~V}$ to $-0.1 \mathrm{~V}$ with varied scan rate of $25-125 \mathrm{mV} / \mathrm{s}$. The cyclic voltammogram (CV) curves were used to determine specific capacitance (Csp), specific power (Psp) and specific energy (Esp) of the supercapacitor model.
\end{abstract}

Keywords: graphene oxide, supercapacitor, specific capacitance, specific power, specific energy

\section{Pendahuluan}

Superkapasitor merupakan perangkat penyimpanan energi dengan densitas energi yang lebih tinggi dibandingkan dengan kapasitor konvensional dan densitas daya yang lebih tinggi dibandingkan dengan baterai [1]. Perangkat tersebut memanfaatkan permukaan elektroda untuk menyimpan muatan listrik dan mengadsorpsi ion elektrolit sehingga dapat menyimpan daya listrik [2]. Graphene merupakan material karbon dua dimensi yang banyak diteliti sebagai elektroda superkapasitor karena memiliki sifat mekanik, listrik, termal dan optik yang unggul [3]. Graphene Oxide (GO) merupakan prekursor graphene yang perlu direduksi untuk menghilangkan gugus oksigen agar berubah menjadi Reduced Graphene Oxides (RGO). Ada berbagai metoda reduksi yang digunakan seperti reduksi termal 
yang menggunakan pemanasan, fotoreduksi yang menggunakan cahaya, serta reduksi kimia yang menggunakan bahan kimia.

Elektroda berbasis graphene memiliki kapasitansi spesifik besar yang bergantung pada berbagai faktor antara lain metode persiapan, luas permukaan spesifik, jumlah lapisan dalam graphene multilayer serta elektrolit yang digunakan [4]. Elektroda untuk berbagai aplikasi umumnya termasuk untuk superkapasitor dibuat dalam bentuk lapisan tipis. Cara pembuatan lapisan tipis dan bahan aktif pada kolektor arus harus diperhatikan karena mempengaruhi kinerja superkapasitor [4]. Pada penelitian terdahulu telah dilakukan studi pembuatan lapisan tipis RGO dengan teknik spin coating [5, 6], solution casting [7], dan electrochemical deposition [8, $9,10]$ Namun teknik-teknik tersebut belum dapat membuat lapisan dalam skala besar, padahal untuk aplikasi divais secara umum dibutuhkan teknik deposisi yang dapat menghasilkan lapisan dalam ukuran besar agar dapat diaplikasikan pada jalur produksi. Telah dilaporkan pembuatan lapisan GO yang memungkinkan pembuatannya secara massal dalam skala besar yaitu dengan teknik spraying [11]. Teknik tersebut juga mengurangi pemborosan material pada proses pelapisan dibanding metode konvensional seperti teknik spin coating karena tidak ada material yang terbuang.

Dalam penelitian ini akan dilakukan pembuatan lapisan GO untuk elektroda superkapasitor. Pembuatan lapisan GO dilakukan dengan teknik UV oven spraying yaitu modifikasi teknik spraying yang berkaitan dengan kebutuhan reduksi pada material GO. Proses spraying dilakukan pada ruang tertutup (oven spraying box) dengan penyinaran lampu merkuri secara in-situ. Dengan demikian diharapkan proses reduksi berlangsung bersamaan dengan proses deposisi lapisan GO sehingga gugus oksigen pada GO dapat dikurangi.

\section{Metode Penelitian}

Bahan yang digunakan adalah dispersi GO komersial (Graphenea SA ES A75022608) sebagai bahan aktif, pelat $\mathrm{Cu} 0,2 \mathrm{~mm}$ (Nilaco) sebagai current collector superkapasitor, bubuk $\mathrm{KCl}$ sebagai bahan elektrolit pada pengukuran Cyclic Voltammetry (CV), miliQ-water sebagai pelarut. Sebelum dideposisi, konsentrasi GO diencerkan menjadi $0,5 \mathrm{mg} / \mathrm{mL}$ dengan milli- $Q$ water dan selanjutnya agar dispersi GO tersebut homogen maka dilakukan sonikasi dengan ultrasonic bath selama 30 menit.

Pelapisan GO diawali dengan persiapan ruang diawali dengan menyalakan lampu merkuri selama 15 menit agar pencahayaan dan suhu oven stabil, pemasangan substrat, penyiapan alat spraying dan dispersi GO dalam botol spraying. Pelapisan dispersi GO pada pelat $\mathrm{Cu}$ dilakukan secara manual dan berulang sebanyak $25 \mathrm{kali}$ pelapisan. Ada jeda waktu pengulangan sekitar 4 menit yang bertujuan agar lapisan sebelumnya sudah kering sebelum dilakukan pelapisan berikutnya. Setelah tahap pelapisan selesai, sampel tersebut dibiarkan selama 15 menit dalam oven agar lapisan tersebut dapat kering secara sempurna.

Lapisan GO yang dihasilkan langsung digunakan sebagai elektroda tanpa proses reduksi lebih lanjut. Ada dua variasi model sel superkapasitor yang dibuat yaitu pasangan sel elektroda $\mathrm{GO}$ dengan platina $(\mathrm{Cu} \mid \mathrm{GO}-\mathrm{Pt})$ dan pasangan sel elektroda GO dengan $\mathrm{GO}(\mathrm{Cu}|\mathrm{GO}-\mathrm{Cu}| \mathrm{GO})$ seperti yang diperlihatkan pada Gambar 1(a) dan (b). 


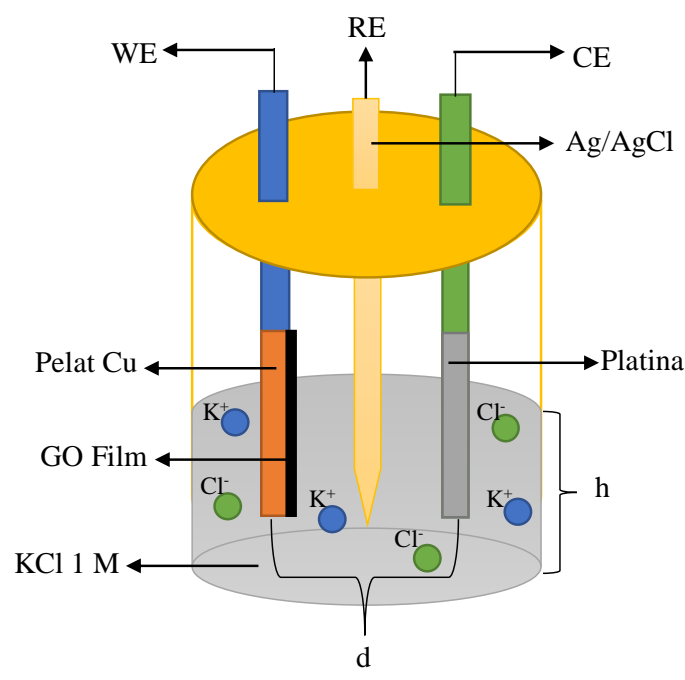

(a)

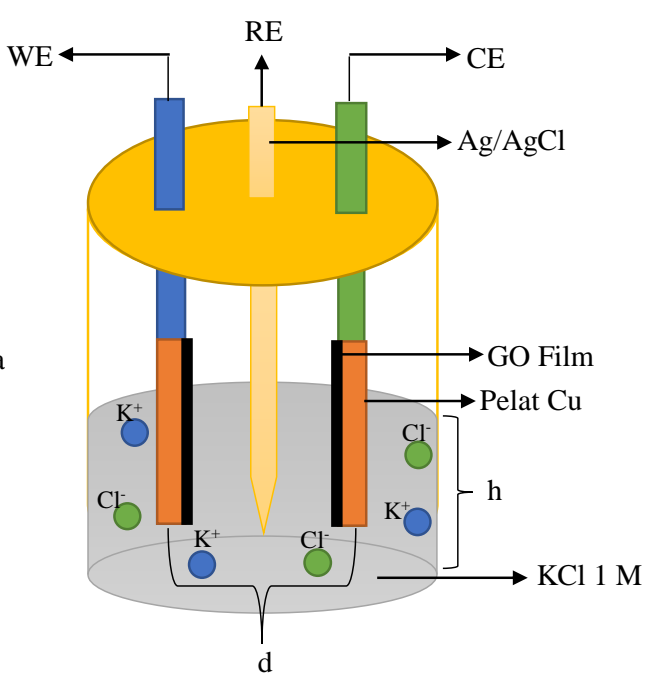

(b)

Gambar 1. Skema pengukuran CV elektroda superkapasitor model sel Cu|GO-Pt (a), $\mathrm{Cu} \mid \mathrm{GO}$ $\mathrm{Cu} \mid \mathrm{GO}(\mathrm{b})$

Karakteristik elektroda $\mathrm{Cu} \mid \mathrm{GO}$ diukur dengan Cyclic Voltammetry (CV) secara potentiostatic untuk mengamati sifat kapasitif dari elektroda $\mathrm{Cu} \mid \mathrm{GO}$ menggunakan kurva histeresis CV arus terhadap tegangan. Pengukuran CV pada sel elektroda tunggal dilakukan dengan konfigurasi 3 elektroda yaitu lapisan $\mathrm{Cu} \mid \mathrm{GO}$ sebagai elektroda kerja (working electrode), $\mathrm{Ag} / \mathrm{AgCl}$ sebagai elektroda referensi (reference electrode) dan platina sebagai elektroda lawan (counter electrode). Pengukuran $\mathrm{CV}$ pada sel elektroda ganda juga menggunakan konfigurasi 3 elektroda dengan $\mathrm{Ag} / \mathrm{AgCl}$ sebagai elektroda referensi dan pasangan $\mathrm{Cu} / \mathrm{GO}$ sebagai elektroda kerja dan elektroda lawan. Pengukuran CV dilakukan pada rentang tegangan $-1,0 \mathrm{~V}$ sampai $-0,1 \mathrm{~V}$ dan variasi scan rate antara $25-125 \mathrm{mV} / \mathrm{s}$.

\section{Hasil dan Pembahasan}

Karakteristik lapisan $\mathrm{GO}$ yang dihasilkan pada pelat $\mathrm{Cu}$ dengan jumlah pengulangan 25 kali secara visual tampak gelap dengan berwarna kecoklatan dan menutupi seluruh permukaan pelat $\mathrm{Cu}$ pada satu sisi. Secara visual tampak bahwa semakin banyak jumlah pengulangan deposisi, maka lapisan GO yang terbentuk juga semakin tebal. Lapisan yang didapat diukur karakteristiknya dengan CV.

Hasil pengukuran CV secara potentiostatic memperlihatkan bentuk kurva histeresis berupa respon arus terhadap siklus tegangan yang diberikan ketika tegangan dinaikkan dari $-1,0 \mathrm{~V}$ hingga $-0,1 \mathrm{~V}$ dan diturunkan kembali ke tegangan $-1,0 \mathrm{~V}$ seperti tampak pada Gambar 2. Histeresis tersebut mengindikasikan ketika sel diberikan tegangan terjadi mekanisme penyimpanan muatan akibat akumulasi muatan pada permukaan elektroda $\mathrm{Cu} \mid \mathrm{GO}$ dan elektrolit $1 \mathrm{M} \mathrm{KCl}$. Kurva histeresis $\mathrm{CV}$ tersebut memiliki puncak dan lembah yang menggambarkan proses reaksi redoks yang berkaitan dengan peristiwa serah terima elektron pada permukaan elektroda $\mathrm{Cu} \mid \mathrm{GO}$. Kurva histeresis tersebut menunjukkan elektroda $\mathrm{Cu} \mid \mathrm{GO}$ memiliki sifat kapasitif yang ideal sehingga dapat menyimpan muatan listrik secara 
elektrostatis dengan mengikuti siklus adsorpsi-desorpsi ion elektrolit secara reversible pada permukaan elektroda.

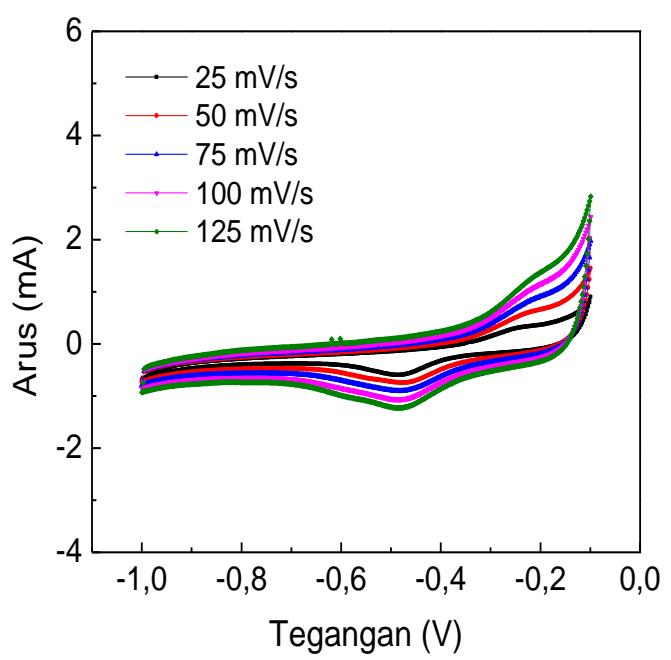

(a)

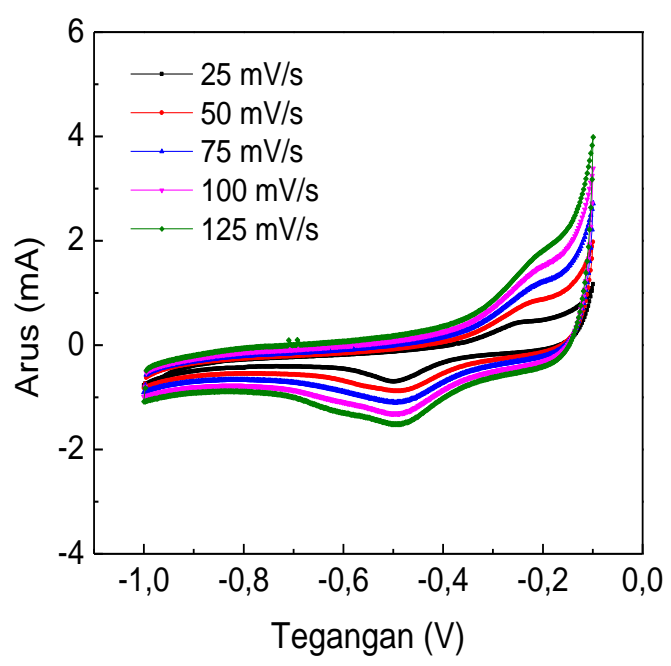

(b)

Gambar 2. Kurva Histeresis CV elektroda superkapasitor model sel tunggal (Cu|GO-Pt) (a), model sel ganda $(\mathrm{Cu}|\mathrm{GO}-\mathrm{Cu}| \mathrm{GO})(\mathrm{b})$.

Seperti tampak pada Gambar 2, variasi scan rate mempengaruhi luas histeresis CV, yang mana semakin besar scan rate maka semakin besar luas histeresis CV. Hal tersebut berkaitan dengan besar scan rate yang menyatakan besarnya kenaikan tegangan tiap satuan waktu. Kurva histeresis yang dihasilkan memiliki bentuk yang identik sama walaupun kuasi persegi menjadi lebar akibat adanya perubahan scan rate. Hal ini mengindikasikan bahwa elektroda $\mathrm{Cu} \mid \mathrm{GO}$ cenderung stabil dalam menyimpan muatan serta menunjukkan adanya transmisi muatan pada elektroda $\mathrm{Cu} \mid \mathrm{GO}$.

Selain scan rate, variasi model sel superkapasitor juga mempengaruhi kurva histeresis $\mathrm{CV}$ yang dihasilkan, yang mana model sel elektroda ganda $(\mathrm{Cu} \mid \mathrm{GO}-$ $\mathrm{Cu} \mid \mathrm{GO})$ memiliki luas area histeresis yang lebih besar dibanding model sel elektroda tunggal $(\mathrm{Cu} \mid \mathrm{GO}-\mathrm{Pt})$. Hal tersebut mengindikasikan bahwa model sel elektroda ganda $(\mathrm{Cu}|\mathrm{GO}-\mathrm{Cu}| \mathrm{GO})$ memiliki mekanisme penyimpanan muatan yang lebih efektif dibanding model sel elektroda tunggal.

Luas area histeresis yang diperoleh pada karakteristik CV menggambarkan daya tersimpan pada elektroda $\mathrm{Cu} \mid \mathrm{GO}$ dengan satuan Watt. Daya berasal dari perkalian nilai respon arus (i) dan step potensial (dV) yang diberikan yaitu 0,00244 V. Dari luas area histeresis $\mathrm{CV}$ yang diolah menggunakan persamaan 1. diperoleh daya spesifik (per satuan luas) untuk kedua model sel seperti Gambar 3.

$$
P_{S P}=\frac{\int_{-0,1}^{-1,0} i_{o} d V+\int_{-1.0}^{-0,1} i_{r} d V}{A}
$$

Daya spesifik elektroda $\mathrm{Cu} \mid \mathrm{GO}$ untuk kedua model sel ditinjau pada scan rate terbesar $(125 \mathrm{mV} / \mathrm{s})$. Seperti pada Gambar 3. kurva daya spesifik model sel elektroda ganda lebih tinggi dibanding model sel elektroda tunggal. Hal ini 
mengindikasikan bahwa kapasitas penyimpanan muatan di anoda maupun di katoda pada model sel elektroda ganda lebih besar.

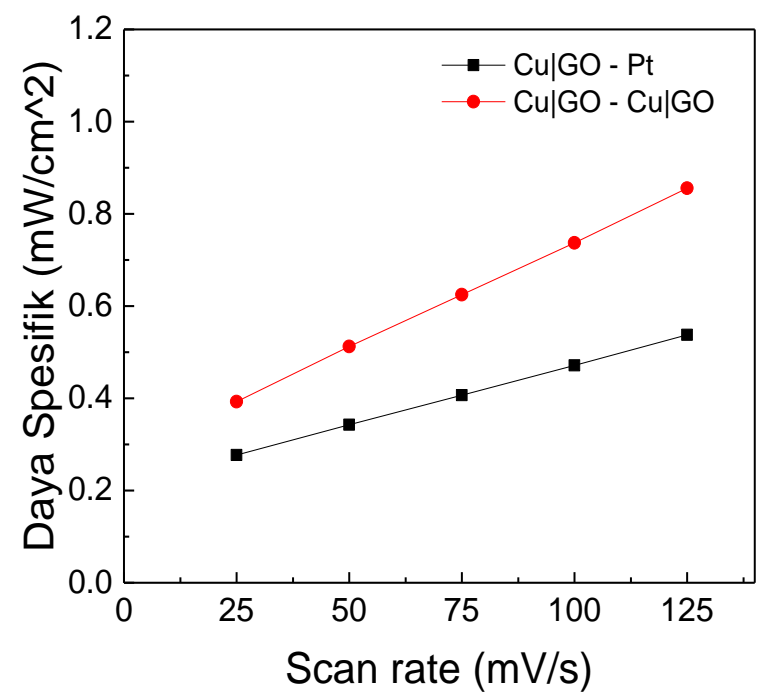

Gambar 3. Perbandingan daya spesifik terhadap perubahan scan rate model sel elektroda tunggal $(\mathrm{Cu} \mid \mathrm{GO}-\mathrm{Pt})$ dan model sel elektroda ganda $(\mathrm{Cu}|\mathrm{GO}-\mathrm{Cu}| \mathrm{GO})$.

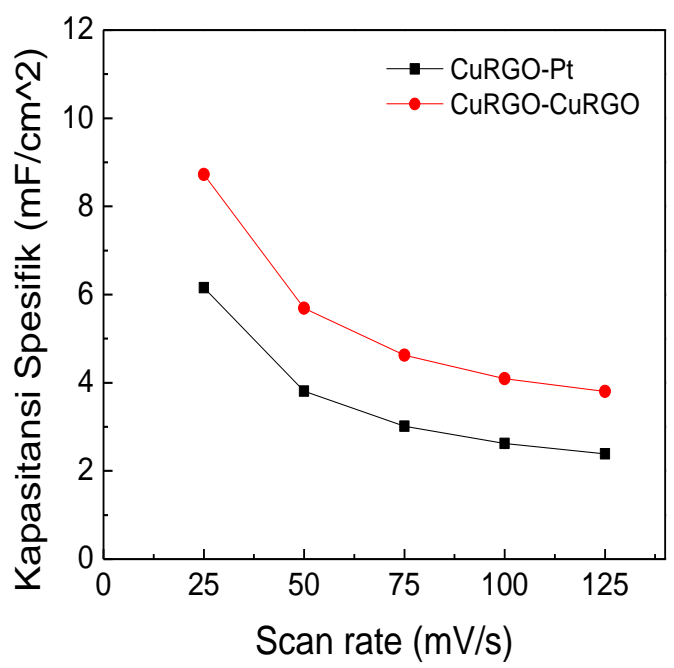

Gambar 4. Perbandingan kapasitansi spesifik terhadap perubahan scan rate model sel elektroda tunggal $(\mathrm{Cu} \mid \mathrm{GO}-\mathrm{Pt})$ dan model sel elektroda ganda $(\mathrm{Cu}|\mathrm{GO}-\mathrm{Cu}| \mathrm{GO})$.

Dengan menggunakan Persamaan 2. diperoleh kurva kapasitansi spesifik untuk kedua model sel seperti yang diperlihatkan pada Gambar 4.

$$
C_{S P}=\frac{1}{2 A \cdot \Delta V \cdot s}\left(\int_{-0,1}^{-1,0} i_{o} d V+\int_{-1.0}^{-0,1} i_{r} d V\right)
$$

Analisa kapasitansi spesifik ditinjau pada scan rate terkecil $(25 \mathrm{mV} / \mathrm{s})$. Dari kurva kapasitansi spesifik kedua model sel tersebut terlihat bahwa kapasitansi spesifik model sel elektroda ganda lebih tinggi dibanding model sel elektroda tunggal. Jika nilai kapasitansi spesifik semakin besar, maka muatan yang tersimpan pada 
elektroda semakin banyak. Muatan tersebut berasal dari akumulasi muatan elektrostatik pada bidang batas permukaan elektroda-elektrolit dan akibat adanya reaksi redoks yang terjadi pada elektroda-elektrolit. Selain itu, kurva kapasitansi spesifik yang diperoleh berbanding terbalik terhadap perubahan scan rate. Semakin besar scan rate, kapasitansi spesifik yang diperoleh semakin kecil dengan bentuk kurva awal turun pada scan rate $25 \mathrm{mV} / \mathrm{s}$ dan menjadi relatif tak berubah pada scan rate $50 \mathrm{mV} / \mathrm{s}$ sampai dengan scan rate $125 \mathrm{mV} / \mathrm{s}$. Hal tersebut mengindikasikan bahwa ketika scan rate diperbesar, waktu pencuplikan data pada CV semakin cepat sehingga akumulasi ion-ion elektrolit yang melekat pada permukaan elektroda menjadi lebih sedikit. Begitupun sebaliknya, ketika scan rate diperkecil, waktu pencuplikan data pada CV semakin lambat sehingga akumulasi ion-ion yang melekat ada permukaan elektroda menjadi lebih banyak.

Dengan menggunakan persamaan 3. diperoleh kurva energi spesifik untuk kedua model sel seperti yang diperlihatkan pada Gambar 5.

$$
E_{S P}=\frac{1}{4 A \cdot \Delta V \cdot s}\left(\int_{-1,0}^{-0,1} i_{o} d V+\int_{-0,1}^{-1,0} i_{r} d V\right) V^{2}
$$

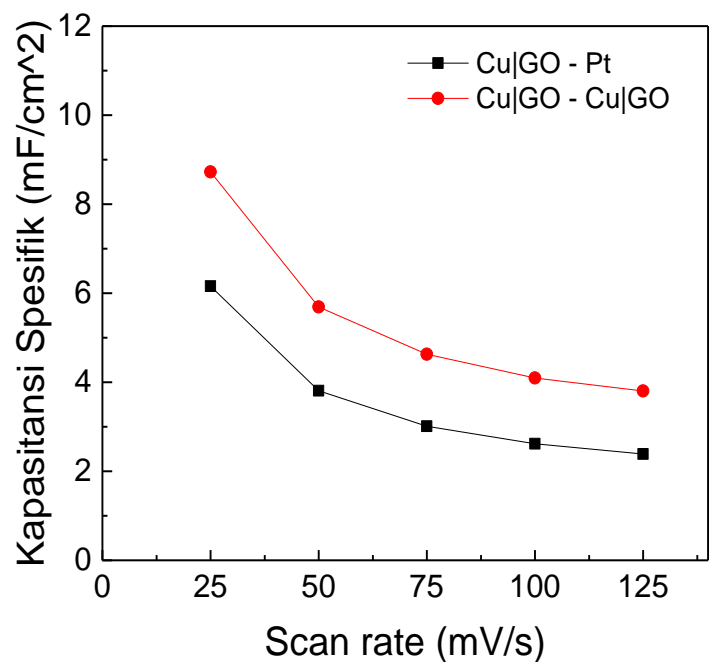

Gambar 5. Perbandingan energi spesifik terhadap perubahan scan rate model sel elektroda tunggal $(\mathrm{Cu} \mid \mathrm{GO}-\mathrm{Pt})$ dan model sel elektroda ganda $(\mathrm{Cu}|\mathrm{GO}-\mathrm{Cu}| \mathrm{GO})$.

Analisa energi spesifik juga ditinjau pada scan rate terkecil $(25 \mathrm{mV} / \mathrm{s})$. Berdasarkan diagram Ragone plot superkapasitor, daya spesifik memiliki hubungan berbanding terbalik terhadap energi spesifik karena daya merupakan energi per satuan waktu. Hal ini juga berkorelasi dengan nilai scan rate yang diberikan pada saat pengukuran $\mathrm{CV}$. Apabila scan rate diperbesar $125 \mathrm{mV} / \mathrm{s}$ maka respon arus yang muncul pada kurva juga semakin besar sehingga waktu yang dibutuhkan untuk menyelesaikan satu siklus CV menjadi lebih singkat yang mengindikasikan bahwa energi tersimpan kecil, sedangkan daya tersimpan besar. Begitupun sebaliknya apabila scan rate diperkecil $25 \mathrm{mV} / \mathrm{s}$ maka respon arus yang muncul pada karaktersitik CV juga semakin kecil sehingga waktu yang dibutuhkan untuk membentuk satu siklus CV menjadi lebih lama yang mengindikasikan bahwa energi tersimpan besar, sedangkan daya tersimpan kecil. Dengan demikian, scan rate sangat mempengaruhi 
daya dan energi tersimpan pada sel superkapasitor. Nilai daya spesifik, kapasitansi spesifik dan energi spesifik dari kedua model sel superkapasitor ditunjukkan pada Tabel 1.

Tabel 1. Perbandingan daya spesifik, kapasitansi spesifik, dan energi spesifik model sel superkapasitor

\begin{tabular}{cccc}
\hline No. & Parameter & Cu|GO-Pt & Cu|GO-Cu|GO \\
\hline 1. & Daya Spesifik $\left(\mathrm{mW} / \mathrm{cm}^{2}\right)$ & 0,54 & 0,86 \\
2. & Kapasitansi Spesifik $\left(\mathrm{mF} / \mathrm{cm}^{2}\right)$ & 6,16 & 8,72 \\
3. & Energi Spesifik $\left(\mu \mathrm{Wh} / \mathrm{cm}^{2}\right)$ & 0,69 & 0,98 \\
\hline
\end{tabular}

Kriteria performa sel superkapasitor pada penelitian sebelumnya $[10,12]$ ditunjukkan dengan nilai kapasitansi spesifik yang berkisar antara 6,5 - 27,3 $\mathrm{mF} / \mathrm{cm}^{2}$. Tampak pada Tabel 1 bahwa elektroda $\mathrm{Cu} / \mathrm{GO}$ dengan jumlah pengulangan deposisi sebanyak 25 kali berada pada rentang kriteria superkapasitor. Hasil ini mengindikasikan bahwa lapisan GO yang dibuat dengan dengan teknik UV oven spraying dengan jumlah pengulangan deposisi sebanyak 25 kali setara dengan lapisan RGO dan memiliki karakteristik dalam kategori superkapasitor.

\section{Kesimpulan}

Hasil karakterisasi CV menunjukkan lapisan $\mathrm{Cu} \mid \mathrm{GO}$ yang dibuat dengan teknik UV oven spraying dapat digunakan sebagai elektroda superkapasitor. Parameter daya spesifik, kapasitansi spesifik dan energi spesifik yang diperoleh dari sel tunggal dan sel ganda yang menggunakan lapisan $\mathrm{Cu} \mid \mathrm{GO}$ dengan jumlah pengulangan deposisi 25 kali sudah tergolong kedalam kriteria superkapasitor. Model sel elektroda ganda $(\mathrm{Cu}|\mathrm{GO}-\mathrm{Cu}| \mathrm{GO})$ memiliki potensi yang lebih unggul dibanding model sel elektroda tunggal $(\mathrm{Cu} \mid \mathrm{GO}-\mathrm{Pt})$. Hal ini berkaitan dengan daya tersimpan yang lebih besar seiring meningkatnya ketebalan lapisan GO akibat penambahan jumlah pelapisan.

\section{Ucapan terima kasih}

Penelitian ini didanai oleh PDUPT kontrak no 2938/UN6.D/LT/2019, tanggal 2 April 2019

\section{DaftarPustaka}

1. B. E. Conway. Electrochemical supercapacitors scientific fundamentals and technological applications. Advances in Lithium-Ion Batteries (1999) pp. 481505.

2. A. G. Pandolfo and A. F. Hollenkamp. Carbon properties and their role in supercapacitors. vol. 157, no. 1 (2006) pp. 11-27.

3. H. Choi, S. Jung, J. Seo, and D. Wook. Graphene for energy conversion and storage in fuel cells and supercapacitors. Nano Energy, vol. 1, no. 4 (2012) pp. 534-551.

4. Dale A.C. Brownson, Dimitrios K. Kampouris, Craig E. Banks, An overview of graphene in energy production and storage applications. Journal of Power Sources 196 (2011) 4873-4885. 
5. Fitrilawati, Norman Syakir, Annisa Aprilia, Z. Liu, X. Feng, K. Muellen, C. Bubeck, Reduction kinetic and stability of Graphene Oxide Thin Films, Material Science Forum Vol. 827 (2015) page 317-320

6. Vika Marcelina, Fitri Yuliasari, Yeni W Hartati, Fitrilawati, dan Norman Syakir. Pembuatan Lapisan Tipis Oksida Grafena Tereduksi sebagai Material Elektroda Sistem Kapasitor dan Karakterisasinya. Jurnal Fisika dan Aplikasinya, Vol. 13 No. 3 (2017) 112-114.

7. Diyan Unmu Dzujah, Vika Marcelina, Norman Syakir, Ayi Bahtiar, Fitrilawati. Charge-discharge Model Superkapasitor RGO dalam Sistem Elektrolit KCl. Jurnal Ilmu dan Inovasi Fisika Vol. 02 No. 01 (2018) 65 - 69.

8. Vika Marcelina, Hanifah Andini, Norman Syakir, Ayi Bahtiar, Yeni W. Hartati, Santhy Wyantuti, Fitrilawati. Preparation of Graphene Oxide Thin Film Using Electrochemical Cyclic Potentiostatic Method. Journal of Physics Conference Series 1080 (2018) 012028

9. Norman Syakir, Hanifah Andini, Vika Marcelina, Ayi Bahtiar, Yeni W. Hartati, Santhy Wyantuti, Fitrilawati. Application of Electrochemical Deposited Graphene Oxide Films as Supercapacitor Electrode. Journal of Physics Conference Series 1080 (2018) 012044

10. Fitrilawati, Vika Marcelina, Diyan Unmu Dzujah, Ayi Bahtiar,Yeni Wahyuni Hartati, Norman Syakir. Energy Storage Characteristics of Electrochemically Deposited Graphene Oxide on ITO and $\mathrm{Cu}$ Substrates. Materials Science Forum Vol. 966 (2019) pp 428-432.

11. M. Beidaghi, Z. Wang, L. Gu, and C. Wang. Electrostatic spray deposition of graphene nanoplatelets for high-power thin-film supercapacitor electrodes. J. Solid State Electrochem, Vol. 16 No. 10 (2012) pp. 3341-3348.

12. B. Wei, H. Liang, D. Zhang, Z. Qi, H. Shen, and Z. Wang. Magnetron sputtered TiN thin films toward enhanced performance supercapacitor electrodes. Mater. Renew. Sustain. Energy (2018) pp. 1-9. 